\title{
Age Changes in Hand Measurements of the Punjabi Boys at
}

\section{Adolescence}

\author{
Raghbir SingH \\ Department of Anthropology, University of Delhi, Delhi-7, India
}

\begin{abstract}
In the present paper the mean values, standard deviations, rates of growth, distance and velocity curves of hand length and hand breadth of 400 Punjabi speaking Hindu Khatri (an endogamous caste) boys aged 11 to 18 years are presented. The values of correlation coefficient ' $r$ ' between hand length and stature; hand breadth and stature and between hand length and hand breadth are also reported separately for each age group.
\end{abstract}

While adequate information is now available on the appearance of ossification centres of hand and wrist etc. of Indian children, comparatively much less is known about the physical growth of hand. Information on the relationship of hand measurements with stature during growth of Indian population groups is also extremely scanty so far. Since hand measurements provide valuable data on physical growth and development of children, the present study was attempted.

\section{MATERIAL AND METHOD}

Standardised measurements of hand length and hand breadth of 400 Punjabi speaking Hindu 'Khatri' (an endogamous group) boys aged 11 to 18 years from the city of Delhi (vide Singh, 1968) formed the material for the present study. The techniques of taking the measurements were those of MARTIN (1928) but the measurements were recorded to the nearest $0.1 \mathrm{~cm}$ (A battery of 13 other measurements were also obtained from those boys, but those measurements are reserved for the later treatment).

Punjabis conform to the 'Mediterranean' type of GuHA (1944) and form one of the important population groups of North India.

50 boys were measured in each age group from 11 to 18 years and the convention of expressing the age at the last birth day was followed for the present study. Thus 11 years age group included all the children who had completed 11 years but had not reached their 12th birthday at the time of their measurements. If a child was measured exactly on his 12th birthday, he was put in the age group of 12 years. On the other hand if a child was measured even one day before his 12 th birth day, he was placed in the 11 years age group. The mean ages of the boys in each of the 8 age groups from 11 to 18 years inclusive were $11.47,12.48,13.51,14.53$, 
15. $46,16.45,17.44$ and 18.44 years respectively.

\section{RESULTS AND DISCUSSION}

The mean values, standard deviations and rate of growth of hand length are given in Table 1 . The distance curve of hand length based on the mean values at different age groups and velocity curve or growth curve based on absolute growth between the different age groups are presented in Fig. 1.

There was a continuous increase in the mean values of hand length from 11 through 17 years. After 17 years age group there was a decrease of a 0.25 $\mathrm{cm}$ in the mean value. This may be due to unconcious sampling errors. Maximum increase $(0.95 \mathrm{~cm})$ or spurt was observed between 12 and 13 years age groups. Study of increasing standard deviations also support the observation that maximum spurt in hand length occured between 12 and 13 years age groups. Standard deviation of $1.16 \mathrm{~cm}$ was highest at 13 years age group and this may be due to the fact that at this age group some children grew slowly while others grew very fast and hence a high value of standard deviation.

The finding of minimum $(0.1 \mathrm{~cm})$ increase in hand length after 16 years and a lowering of the mean value after 17 years age group indicated that growth in hand length perhaps stopped after 17 years of age.

Hand breadth also showed a continuous increase in the mean values from 11 through 17 years. Maximum spurt

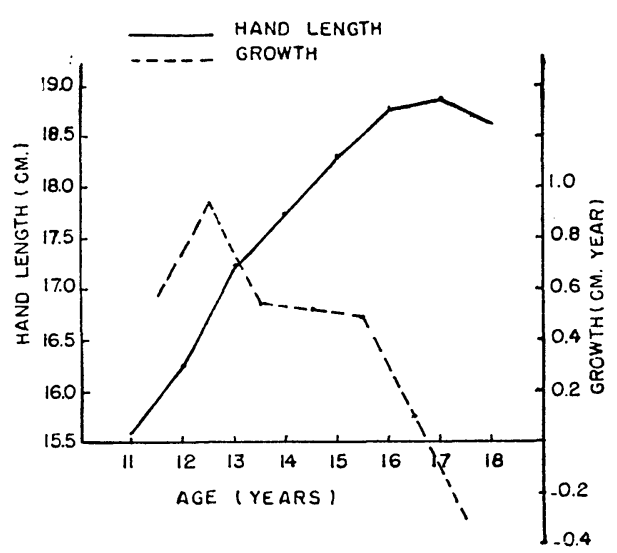

Fig. 1. Distance and velocity curves of hand length in Punjabi boys.

Table 1. Mean values, standard deviations and rate of growth of hand length $(\mathrm{cm})$ in Punjabi boys.

\begin{tabular}{|c|c|c|c|c|c|}
\hline \multirow{2}{*}{$\begin{array}{l}\text { Age groups } \\
\text { (years) }\end{array}$} & \multirow{2}{*}{ No. } & \multirow{2}{*}{ Mean } & \multirow{2}{*}{ S. D. } & \multicolumn{2}{|c|}{ Growth } \\
\hline & & & & Absolute & $\%$ per annum \\
\hline 11 & 50 & 15.66 & 0.96 & 0.58 & 3.70 \\
\hline 12 & 50 & 16.24 & 1.09 & 0.95 & 5.85 \\
\hline 13 & 50 & 17.19 & 1.16 & 0.56 & 3.26 \\
\hline 14 & 50 & 17.75 & 0.93 & 0.53 & 2.99 \\
\hline 15 & 50 & 18.28 & 1.07 & 0.50 & 2.74 \\
\hline 16 & 50 & 18.78 & 1.05 & 0.10 & 0.53 \\
\hline 17 & 50 & 18.88 & 0.90 & $\begin{array}{r}0.10 \\
-0.25\end{array}$ & -1.32 \\
\hline 18 & 50 & 18.63 & 0.80 & & \\
\hline
\end{tabular}


Table 2. Mean values, standard deviations and rate of growth of hand breadth $(\mathrm{cm})$ in Punjabi boys.

\begin{tabular}{ccccccc}
\hline \multirow{2}{*}{$\begin{array}{c}\text { Age groups } \\
\text { (years) }\end{array}$} & No. & Mean & S. D. & \multicolumn{2}{c}{ Growth } \\
\cline { 6 - 6 } & & & & & Absolute & $\%$ per annum \\
\hline 11 & 50 & 6.50 & 3.34 & & 0.30 & 4.62 \\
12 & 50 & 6.80 & 0.55 & 0.33 & 4.85 \\
13 & 50 & 7.13 & 0.56 & 0.21 & 2.95 \\
14 & 50 & 7.34 & 0.52 & 0.26 & 3.54 \\
15 & 50 & 7.60 & 0.45 & 0.27 & 3.55 \\
16 & 50 & 7.87 & 0.49 & 0.08 & 1.02 \\
17 & 50 & 7.95 & 0.43 & -0.03 & -0.38 \\
18 & 50 & 7.92 & 0.41 & & \\
\hline
\end{tabular}

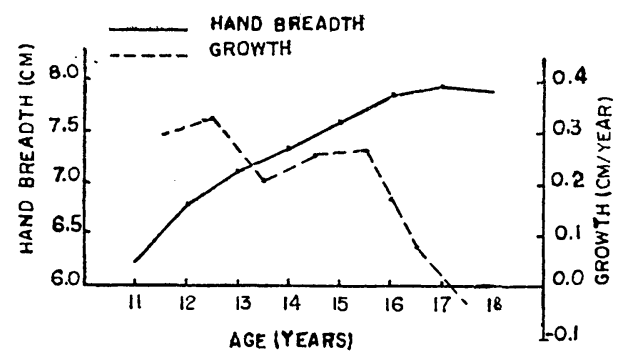

Fig. 2. Distance and velocity curves of hand breadth in Punjabi boys.

of $0.33 \mathrm{~cm}$ was observed between 12 and 13 years age groups and minimum growth of $0.08 \mathrm{~cm}$ was noticed between $1_{6}$ and 17 years age groups(Table 2, Fig. 2). After 17 years the mean value of hand breadth decreased by $0.03 \mathrm{~cm}$ only. These observations suggest that growth in hand breadth perhaps stopped after 17 years of age.

The values of correlation coefficients ' $r$ ' between hand length and stature; hand breadth and stature and between hand length and hand breadth are set out in Table 3. The mean values and standard deviations of stature measurements are also included in Table 3.

Significantly high positive correlations existed between different pairs of characters. The values of correlation coefficients ' $r$ ' ranged between 0.557 to

Table 3. Correlations between hand length, hand breadth and stature measurements $(\mathrm{cm})$ etc. in Punjabi boys.

\begin{tabular}{|c|c|c|c|c|c|c|}
\hline \multirow{3}{*}{$\begin{array}{c}\text { Age groups } \\
\text { (years) }\end{array}$} & \multirow{3}{*}{ No. } & \multirow{3}{*}{$\begin{array}{c}\text { 'r' } \\
\text { Hand length : } \\
\text { Stature }\end{array}$} & \multirow{3}{*}{$\begin{array}{l}\text { 'r' } \\
\text { Hand breadth: } \\
\text { Stature }\end{array}$} & 'r' & \multirow{2}{*}{\multicolumn{2}{|c|}{ Stature }} \\
\hline & & & & \multirow{2}{*}{$\begin{array}{l}\text { Hand length: } \\
\text { Hand breadth }\end{array}$} & & \\
\hline & & & & & Mean & S. D. \\
\hline 11 & 50 & 0.889 & 0.727 & 0.710 & 138.30 & 6.97 \\
\hline 12 & 50 & 0.829 & 0.693 & 0.757 & 144.09 & 7.29 \\
\hline 13 & 50 & 0.840 & 0.805 & 0.835 & 150.55 & 8.38 \\
\hline 14 & 50 & 0.817 & 0.683 & 0.669 & 155.39 & 7.79 \\
\hline 15 & 50 & 0.842 & 0.742 & 0.736 & 159.26 & 7.82 \\
\hline 16 & 50 & 0.557 & 0.334 & 0.412 & 165.57 & 6.08 \\
\hline 17 & 50 & 0.690 & 0.402 & 0.550 & 167.26 & 5.56 \\
\hline 18 & 50 & 0.708 & 0.518 & 0.616 & 167.92 & 5.98 \\
\hline
\end{tabular}


0.889 for hand length and stature, 0.334 to 0.805 for hand breadth and stature and 0.412 to 0.835 for hand length and hand breadth measurements (Table 3 ). These positive correlations may be due to the fact that during adolescence, hand length, hand breadth and stature all grow though at varying rates and hence positive correlations. But on closer observation of Table 3 , it was interesting to note that at each age group the degree of correlation between hand length and stature was higher than either of the correlations between hand breadth and stature or between hand length and hand breath.

\section{SUMMARY}

The mean values, standard deviations, rates of growth and distance and velocity curves of hand length and hand breadth of 400 Punjabi speaking Hindu 'Khatri' (an endogamous group) boys aged 11 to 18 years are presented. Correlations between hand length and stature; hand breadth and stature and between hand length and hand breadth are also studied.

Maximum spurt in growth for hand length and hand breadth was observed between the age groups of 12 and 13 years.

Significant and positive correlations were observed between different parameters.

\section{REFERENCES}

GuHA, B. S. 1944: Racial elements in the populations. Oxford University Press, Oxford.

MARTin, R. 1928: Lehrbuch der Anthropologie, Jena, G. Fischer Verlag.

SiNGH, R. 1968: Somatometric study of the Punjabi Hindu Khatri (male) with special emphasis on growth (cross sectional) and relationship between arm girth and body weight measurements. Unpublished $\mathrm{Ph}$. D. thesis of Delhi University 1968.

(Received October 31, 1969)

パンジャブ人男少の青年期に扎ける手計测值の企橎変化

Raghbir SingH

Department of Anthropology, University of Delhi, Delhi-7, India

パンジャブ人は地中海人種型を示す北インドの重要な集団の一つであるが，その内婚的カースト Khatri に 属する 11 藏から 18 歳までの男児 400 名について手長および手幅の年舲変化が調べられた.

各年齢階級の手長（第 1 表，第 1 図）および手幅（第 2 表，第 2 図）の平均値, 標準偏差, 年間成長率加ら, 両計測值とも 12 歳と 13 蔵との間に最大增加が認められた. 增加は 16 歳を過ぎると小さくなり, 17 歳で成 長の停止を示した，手長の標準偏差は 13 歳において最大であったが，乙れは個体間の成長の遅速の現われに よると思われる。

また手長，手幅，身長の間の相関係数 (第 3 表) は，どの組合せについても各年齢階級とも有意の正相関が あるととを示した。 